\title{
New and significant bird records from Rio Grande do Sul, with comments on biogeography and conservation of the southern Brazilian avifauna
}

\author{
Glayson A. Bencke
}

Museu de Ciências Naturais, Fundação Zoobotânica do Rio Grande do Sul, Rua Dr. Salvador França 1427, 90690-000 Porto Alegre, RS, Brazil. (gabencke@fzb.rs.gov.br)

\begin{abstract}
I report on the occurrence of 16 species of birds in Rio Grande do Sul, southern Brazil, of which seven are new for the state - Accipiter superciliosus (Linnaeus, 1766), Brotogeris tirica (Gmelin, 1788), Hemitriccus margaritaceiventer (d'Orbigny \& Lafresnaye, 1837), Phyllomyias griseocapilla Sclater, 1862, Saltator coerulescens Vieillot, 1817, Orthogonys chloricterus (Vieillot, 1819), and Sporophila lineola (Linnaeus, 1758) - and seven were previously known from unsubstantiated or poorly documented records - Ixobrychus exilis (Gmelin, 1789), Brotogeris chiriri (Vieillot, 1818), Coccyzus euleri Cabanis, 1873, Pulsatrix koeniswaldiana (Bertoni \& Bertoni, 1901), Psilorhamphus guttatus (Ménétriès, 1835), Serpophaga griseicapilla Straneck, 2007, and Hemithraupis ruficapilla (Vieillot, 1818). Descriptive and natural history notes are presented for some of these species. The records of B. tirica, P. guttatus, P. griseocapilla, Myiozetetes similis (Spix, 1825), O. chloricterus, H. ruficapilla, and S. lineola represent significant southward range extensions of up to $300 \mathrm{~km}$. Also, a new confirmed record of Myiarchus ferox (Statius Muller, 1776) is divulged. Finally, I argue that the Atlantic forests of north-eastern Rio Grande do Sul should be included in the Serra do Mar area of endemism (sensu SILVA et al., 2004) because of the presence of Orthogonys chloricterus, and comment on the possible range expansion of Myiozetetes similis, Sporophila lineola and other primarily tropical species in southern Brazil.
\end{abstract}

KEYWORDS. New occurrences, distribution, Atlantic forest, range expansion.

RESUMO. Registros novos ou significativos de aves para o Rio Grande do Sul, Brasil, com comentários sobre biogeografia e conservação da avifauna sul-brasileira. Relato a ocorrência de 16 espécies de aves no Rio Grande do Sul, das quais sete são novas para o estado - Accipiter superciliosus (Linnaeus, 1766), Brotogeris tirica (Gmelin, 1788), Hemitriccus margaritaceiventer (d'Orbigny \& Lafresnaye, 1837), Phyllomyias griseocapilla Sclater, 1862, Saltator coerulescens Vieillot, 1817, Orthogonys chloricterus (Vieillot, 1819) e Sporophila lineola (Linnaeus, 1758) - e outras sete eram previamente conhecidas apenas por registros não documentados ou com documentação deficiente - Ixobrychus exilis (Gmelin, 1789), Brotogeris chiriri (Vieillot, 1818), Coccyzus euleri Cabanis, 1873, Pulsatrix koeniswaldiana (Bertoni \& Bertoni, 1901), Psilorhamphus guttatus (Ménétriès, 1835), Serpophaga griseicapilla Straneck, 2007 e Hemithraupis ruficapilla (Vieillot, 1818). Os registros de B. tirica, P. guttatus, P. griseocapilla, Myiozetetes similis (Spix, 1825), O. chloricterus, $H$. ruficapilla e $S$. lineola representam significativas extensões de distribuição ao sul de até $300 \mathrm{~km}$. Notas descritivas e observações naturalísticas são apresentadas para algumas dessas espécies. Adicionalmente, um novo registro confirmado de Myiarchus ferox (Statius Muller, 1776) é divulgado. Por fim, apresento argumentos em favor da inclusão das florestas atlânticas do nordeste do Rio Grande do Sul na área de endemismo Serra do Mar (sensu Silva et al., 2004), por causa da presença de Orthogonys chloricterus, e comento sobre a possível expansão distribucional de Myiozetetes similis, Sporophila lineola e outras espécies essencialmente tropicais no sul do Brasil.

PALAVRAS-CHAVE. Novas ocorrências, distribuição, Mata Atlântica, expansão de distribuição.

Over the past three decades, the number of bird species recorded in the southern Brazilian state of Rio Grande do Sul (hereafter RGS) has increased at a mean rate of two to three species per year (BENCKE, 2001; BENCKE et al., 2009). This is in spite of the fact that the state now has one of the best-studied avifaunas in Brazil, owing largely to the work of the late William Belton in the 1970s and early 1980s (Belton, 1984, 1985). The most up-todate bird list for the state is that of BENCKE (2001), who listed 624 species, 25 of which representing genuine additions to the previous assessment (i.e., BELTON, 1994). Post-2001 additions of non-marine species were reported or detailed in Grantsau (2002), Bencke et al. (2002), Bencke et al. (2003), Krügel (2003), Agne (2004), BarnetT et al. (2004), RePENNING \& Fontana (2008), Fontana et al. (2008), BECKER (2009), and DAMIANI (2009), amongst others, whilst one other species has since been described as new to science (MAURício, 2005). Here I present information on the occurrence of 16 species in RGS, including seven birds new for the state - Accipiter superciliosus (Linnaeus, 1766), Brotogeris tirica (Gmelin,
1788), Hemitriccus margaritaceiventer (d'Orbigny \& Lafresnaye, 1837), Phyllomyias griseocapilla Sclater, 1862, Saltator coerulescens Vieillot, 1817, Orthogonys chloricterus (Vieillot, 1819), and Sporophila lineola (Linnaeus, 1758) - and seven others for which the few previous records lack physical evidence or are only poorly documented-Ixobrychus exilis (Gmelin, 1789), Brotogeris chiriri (Vieillot, 1818), Coccyzus euleri Cabanis, 1873, Pulsatrix koeniswaldiana (Bertoni \& Bertoni, 1901), Psilorhamphus guttatus (Ménétriès, 1835), Serpophaga griseicapilla Straneck, 2007, and Hemithraupis ruficapilla (Vieillot, 1818). I also provide new southernmost records for seven species $-B$. tirica, $P$. guttatus, P. griseocapilla, Myiozetetes similis (Spix, 1825), O. chloricterus, $H$. ruficapilla, and S. lineola, including significant range extensions for some Atlantic forest endemics, and report on the rediscovery of Myiarchus ferox (Statius Muller, 1776) almost 100 years after its only previous confirmed record in RGS. When relevant, remarks on behaviour, voice, migration, and distribution and conservation status in RGS are included 
for some species. Supporting evidence for the records is supplied in the form of either photographs or sonograms. In some cases I refer to audio or visual documentation presented in other sources. In the accounts below, Atlantic forest endemics are marked with "Atl". Localities cited in the text are shown in Figure 1.

Species accounts. Least Bittern Ixobrychus exilis. The only evidence for the presence of this tiny heron in RGS is a poor quality - albeit diagnostic - photograph of a male found dead in the urban area of Passo Fundo, north-central state, on 9 April 1997 (AgNe, 2004). Unfortunately, the specimen was not preserved (Carlos E. Agne, pers. comm.). There is also an unconfirmed voice record dated 21 February 1998, from near Tiaraju, São Gabriel, in mid-western RGS (BENCKE, 2001). Late afternoon on 29 October 2008, low-pitched, hoarse barks emanating from dense cattail stands deep inside the extensive marshes surrounding the Lagoa do Morro do Forno ( $\left.29^{\circ} 22^{\prime} \mathrm{S}, 49^{\circ} 53^{\prime} \mathrm{W}\right)$, in the state's northern coastal plain, proved to be of this species after two males that were counter-calling at opposite sides of a natural channel were lured in with playback and imitations of their voices. One bird was seen well but briefly from a boat by Andreas Kindel, Ismael Franz and I as it climbed prominently onto the reeds at a short distance from the observers. The other remained hidden in the lower part of the vegetation, skulking furtively amongst cattail stems and occasionally stopping for a while and pointing its bill upward. This bird was tape-recorded before/after playback and two short videos were also made of it (available online at www.fzb.rs.gov.br/museu/videos). The first individual showed a noticeable reddish base to the otherwise yellowish bill, a trace that was less evident in the second individual and seems to vary with the degree of excitement (Kushlan \& Hancock, 2005). This latter bird, observed for a longer period, had a conspicuous dark line extending diagonally below the eye, and also a narrow, black stripe running down the centre of the white chin and throat. Both plumage features are not depicted or described in most field guides and identification manuals (but see NAROsky \& YZuRIETA, 2003), though they appear to be variously present in individuals from different locations within the species' range, as revealed by a search for images of the Least Bittern in the internet. This substantiates KUSHLAN \& HANCOCK's (2005) conclusion that more study is needed of plumage variation in this species. ВенRsтоск (1996) drew attention to the striking difference between the voices of South American and North American forms of the Least Bittern, a subject that also merits further research. Calls tape-recorded in RGS are similar in frequency and note shape to those described by him for the Neotropical races erythromelas and limoncochae, but show a much richer harmonic structure (Fig. 2). These calls also match vocal examples from Argentina, Bolivia and Brazil presented in STRANECK (1990), MAYER (2000) and MinNs et al. (2010), respectively. Unsolicited calls consisted of series of two to eight hillshaped notes given at a rather irregular pace, with intervals between notes ranging from 2.0 to $5.9 \mathrm{~s}$ (median $=3.4 \mathrm{~s}$; $\mathrm{n}=32$ intervals from 11 series by the same individual; one extreme interval of $7.9 \mathrm{~s}$ excluded). Rarely notes were heard singly. Intervals between series varied widely, from as short as $5.2 \mathrm{~s}$ to as long as 2:06 min. Playback seems to have had little or no effect on vocalizations ( 15 between-

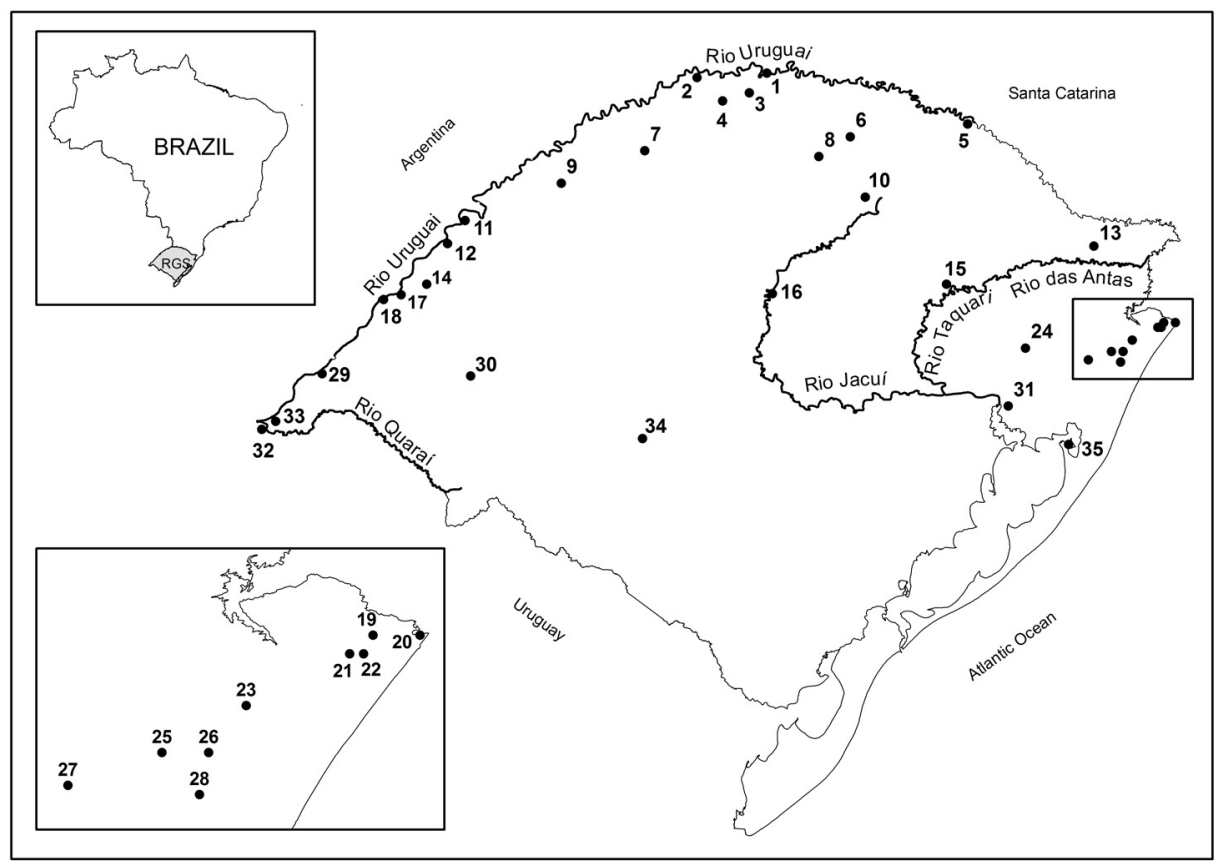

Figure 1. Map of Rio Grande do Sul showing the location of sites mentioned in the text (1, Iraí; 2, Turvo state park; 3, Frederico Westphalen; 4, Guarita indigenous reserve; 5, Espigão Alto state park; 6, Jacutinga; 7, São Valentim; 8, Rondinha state park; 9 , Roque Gonzales; 10, Passo Fundo; 11, Arroio do Salso, São Borja; 12, São Borja; 13, Bom Jesus; 14, São Donato marsh; 15, Cotiporã; 16, Salto do Jacuí; 17, Arroio Pintado Grande, Itaqui; 18, Itaqui; 19, Lagoa do Jacaré; 20, Torres; 21, Lagoa do Morro do Forno; 22, Dom Pedro de Alcântara; 23, Itati; 24, Picada Verão, Sapiranga; 25, Barra do Ouro; 26, Serra Geral biological reserve; 27, Alto Rolante; 28, Maquiné; 29, Uruguaiana; 30, Alegrete; 31, Porto Alegre; 32, Bella Unión, Uruguay; 33, Espinilho state park; 34, São Gabriel; 35, Lagoa do Casamento, Palmares do Sul). 
note intervals from three series ranged 2.1-4.9 s, with median $=3.0 \mathrm{~s}$ ), but notes became softer and somewhat stretched as the bird passed closest to the observers. Least Bitterns from southern Brazil presumably belong to the subspecies erythromelas (see UNDERDOwn, 1933), which ranges widely in cis-Andean South America.
Reported only twice for the neighbouring state of Santa Catarina - the latest record of a bird captured on top of a building at Florianópolis in 1981 (NAKA \& RoDRIGUES, 2000) - but possibly overlooked there.

Tiny Hawk Accipiter superciliosus. On 7 September 2010, a presumed male (Figs 8, 9) was found by me and

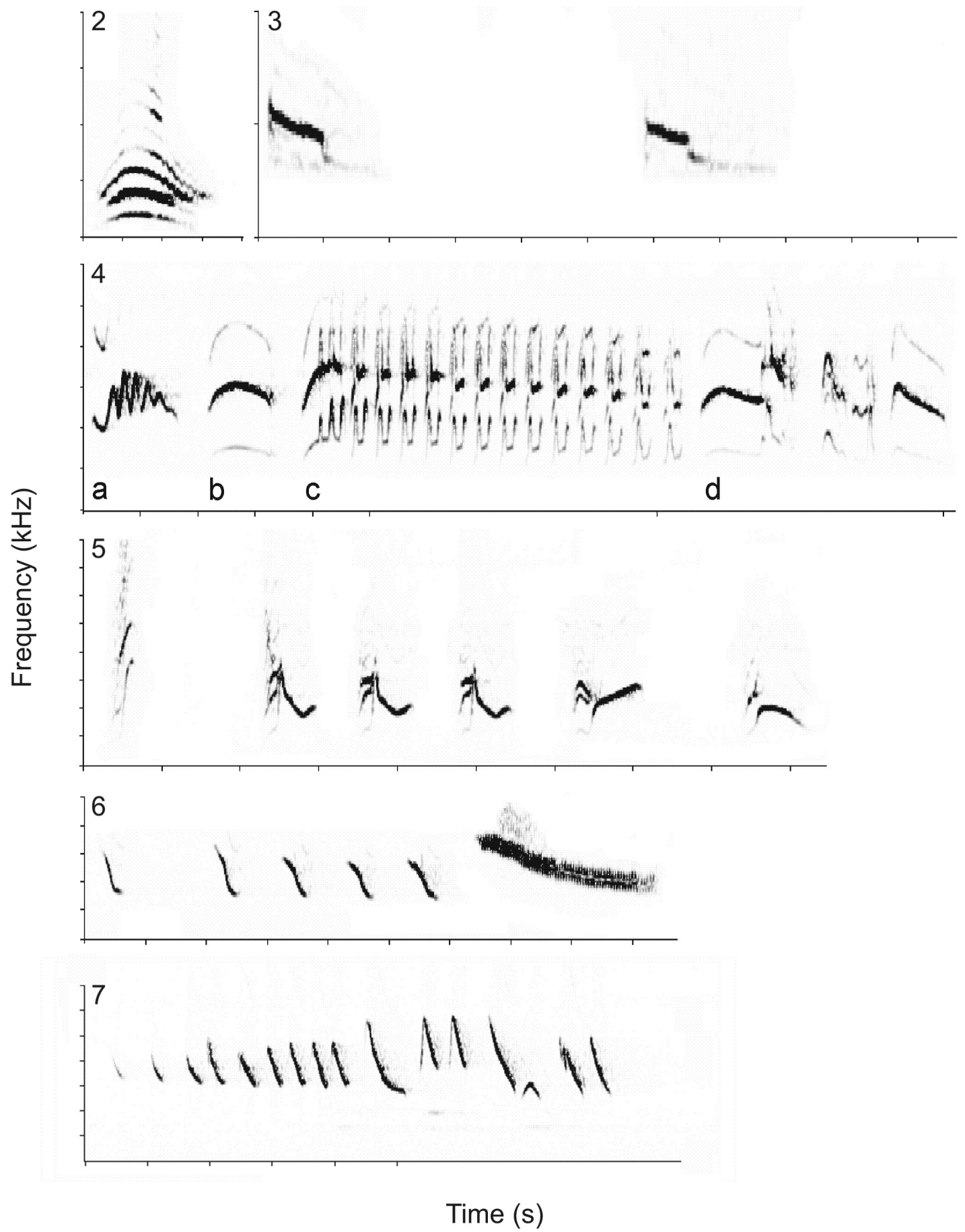

Figures 2-7. Voices of some birds poorly known in or new for Rio Grande do Sul, southern Brazil: 2, Ixobrychus exilis (Gmelin, 1789), note of male advertising call, Lagoa do Morro do Forno, Três Cachoeiras, 29 October 2008; 3, Coccyzus euleri Cabanis, 1873, song (part), Turvo state park, Derrubadas, 12 October 2004; 4, Myiarchus ferox (Statius Muller, 1776) voices recorded at Itaqui, April 2007 (vocal terminology according to Lanyon 1978): a, modulated whistle; b, call; c, rattle; d, a variant of the "hiccup" call, perhaps a type of dawn song; 5, 6, Saltator coerulescens Vieillot, 1817, two types of solo song, Espinilho state park, Barra do Quaraí, 7 February 2002; 7, Sporophila lineola (Linnaeus, 1758), short (typical) song, Maquiné, 26 February 2010. Frequencies in 1-kHz intervals, time in $0.2 \mathrm{~s}$ intervals. All tape recordings by the author. Sonograms produced on a personal computer with CoolEdit96 (Syntrillium Software) at $128(3)$ and $256(2,4-7)$ bands resolution. 
bird photographers Caco Schwertner and Paulo Fenalti in Turvo state park at $27^{\circ} 15^{\prime} 35^{\prime}$ 'S, 5359'52' W (Lajeado do Fábio road, above Rio Turvo), not far from the southwestern border of this 17,500 ha protected area. When first seen, the bird was perched upright on a large leafless tree in open-canopy old secondary forest, probably stillhunting. Suddenly, at 09:05 a.m., it launched itself into the air with closed wings and swooped down overhead toward tree crowns at the opposite side of the trail, disappearing for a while. Within a few seconds, the hawk returned to the same tree with a male Variable Antshrike Thamnophilus caerulescens Vieillot, 1816 in talons, which it began to pluck almost immediately. The bird apparently started by eating the head of its prey, and then the breast, as described by Militello (2005). About 40 min later it flew off carrying the remaining carcass in talons. This is the first record in RGS. Known in Argentina from the adjacent department of San Pedro, Misiones (SEIPKE \& Cabanne, 2002). In Santa Catarina, Rosário (1996) cited (but did not map) a record for Praia Grande, on the border with north-eastern RGS, while Albuquerque \& BRÜGGEMANN (1996) reported its occurrence at Serra do Tabuleiro. According to SoAREs et al. (2008), there are unpublished records also from Urubici and the Barra Grande hydroelectric dam area, on or close to the RGS border.

Plain Parakeet Brotogeris tirica - Atl. Recorded annually between 2003-2005 in May, June, and November-February at Serra Geral biological reserve (29³4-38' S, 50 $\left.11-12^{\circ} \mathrm{W}\right)$, in valleys and slopes covered with undisturbed submontane evergreen forest, and also in eucalyptus groves and orchards of the vicinity, from 200 to $820 \mathrm{~m}$ elevation (one tape recording and several poor quality photographs obtained - Fig. 10). On 19 March 2009, a minimum of ten were in tall eucalyptus inside the nearby village of Barra do Ouro. These first state records represent a range extension of about $170 \mathrm{~km}$ from the nearest localities in Santa Catarina (RosÁRIO, 1996). Well known by local middle-aged bird keepers, who claim the species is present in the region at least since their early youth, so the possibility of either a deliberate introduction or a recent invasion from the north seems unlikely.

Yellow-chevroned Parakeet Brotogeris chiriri. This central Brazilian bird now appears well established in the urban area of Porto Alegre, the state's capital, where it has been noticed since 1997 (see BENCKE, 2001, EFE et al., 2001, and FonTANA, 2005). This population obviously derives from escapees or deliberate releases. Numbers appear to be increasing slowly but, to my knowledge, no breeding information is available to date. Yellowchevroned Parakeets are commonly seen in the city's botanical garden (Fig. 11), where they feed on fruits and seeds of a variety of native and exotic plants, including queen palm Syagrus rommanzoffiana (Arecaceae) and floss-silk tree Chorisia speciosa (Bombacaceae). The species has as yet not been found in adjacent countryside.

Pearly-breasted Cuckoo Coccyzus euleri. This forest-based cuckoo is known in RGS from a single unsubstantiated voice record from Turvo state park, in December 2000 (BENCKE, 2001). On 12 October 2004, I tape-recorded a distant bird within mid-successional forest at $27^{\circ} 15^{\prime} 36^{\prime}$ 'S, $53^{\circ} 59^{\prime} 39^{\prime \prime} \mathrm{W}, 325 \mathrm{~m}$, in the southwestern sector of the park. After persistent playback, I eventually attracted the bird to nearby tree crowns but only had a short glimpse of its silhouette as it moved from one crown to another. No positive visual identification was possible and all I could see was a Coccyzus-like bird with a fairly long and graduated tail. I also tape-recorded a short song composed of three notes (Fig. 3) and heard weak "cow cow cow..." calls reminiscent of the voice of the Dark-billed Cuckoo Coccyzus melacoryphus Vieillot, 1817 after each playback. First definitive sight records in RGS were in October 2010 , when I photographed a single bird on the $21^{\text {st }}$ and saw a pair on the $22^{\text {nd }}$ along the Porto Garcia road, Turvo state park, at 27 14 '21' S, 5358'19'"W (Figs 12, 13). These birds had no trace of rufous on the wings and showed a pale yellowish tinge on belly and undertail coverts (not mentioned in the literature). Following playback, they uttered a rattle similar to that of the Squirrel Cuckoo Piaya cayana (Linnaeus, 1766) but with several staccato "cow..." notes at the end. One secured a caterpillar $1.2 \mathrm{x}$ bill length. The species' distinctive song had been heard earlier, with Giovanni N. Maurício (GNM), about $40 \mathrm{~km}$ to the south-east in the Guarita indigenous reserve $\left(27^{\circ} 25^{\prime} \mathrm{S}\right.$, $53^{\circ} 38^{\prime} \mathrm{W} ; 370 \mathrm{~m}$ ), on 18 December 2002 . This reserve is a mix of cleared areas, small plantations and large tracts of mature forests similar to those at Turvo state park. Considered of probable occurrence in RGS by BENCKE (2001), the Pearly-breasted Cuckoo now qualifies for inclusion in the main state list on the basis of the evidence presented here. Known from adjacent Misiones northward but thought to be only a breeding summer resident south of $20^{\circ} \mathrm{S}$ (BODRATI, 2005; BODRATI et al., 2005; PAYNE, 2005).

Tawny-browed Owl Pulsatrix koeniswaldiana Atl. One was inadvertently captured in a mist net set for bats just outside the town of Salto do Jacuí, central state region, on 14 May 1998 (BENCKE, 2001). The physical evidence for this first state record is published here (Fig. 14). Since then this owl has been found at a number of additional localities in the north and north-east of RGS (BENCKE et al., 2003). These include: Turvo state park (27 ${ }^{\circ} 13^{\prime}$ 'S , 53 $\left.{ }^{\circ} 51^{\prime} \mathrm{W}\right)$, recorded with GNM on 8 August and 14-20 October 2000, and again on 17 December 2002 (with GNM and Cristian M. Joenck) and 9 October 2004 (with nature photographer Adriano Becker - Fig. 15), in deciduous subtropical forest of the upper Rio Uruguai drainage; Rondinha state park $\left(27^{\circ} 54^{\prime} \mathrm{S}, 52^{\circ} 48^{\prime} \mathrm{W}\right), 28$ January 2001, a pair attracted and tape-recorded at early evening by GNM and myself in interior of mixed coniferous-broadleaf forest with huge Araucaria angustifolia (Araucariaceae) pines (a third individual, possibly a juvenile, was with this pair but did not approach); Espigão Alto state park ( $\left.27^{\circ} 37^{\prime} \mathrm{S}, 51^{\circ} 31^{\prime} \mathrm{W}\right)$, 19 February 2001, one seen and tape-recorded at dawn by observers above in old secondary woodland with scattered Araucaria pines near mixed primary forests and clearings; Serra Geral biological reserve, 4 November 2003, single adult seen in the Arroio Encantado valley at 29'36'38' S, 50 11'27' W, 300 m elevation, in moist evergreen forest on the Atlantic slope. Additionally, GNM located and tape-recorded the species on the left margin 
of the lower Rio Carreiro near Cotiporã $\left(29^{\circ} 00^{\prime} S\right.$, $51^{\circ} 42^{\prime} \mathrm{W}$ ), in the highly disturbed remaining forests of the middle Rio Taquari-Antas basin, on 7 October 2003, and the late photographer Norberto Jaeger documented the species in the northern littoral around Torres $\left(29^{\circ} 20^{\prime} \mathrm{S}\right.$, $49^{\circ} 44^{\prime} \mathrm{W}$ ), presumably in lowland coastal forest, at an unspecified date but certainly around 2000. Jaeger's photographs of an adult and young were published in FonTANA et al. (2003) without indication of locality or date. More recently, BERnARDi et al. (2008) and TeIXeIRA et al. (2009) reported the occurrence of the Tawny-browed Owl at Frederico Westphalen, about $40 \mathrm{~km}$ east-southeast of Turvo state park, between 2002-2007. Also, typical Pulsatrix calls heard by me at Picada Verão (29 $33^{\prime}$ 'S,
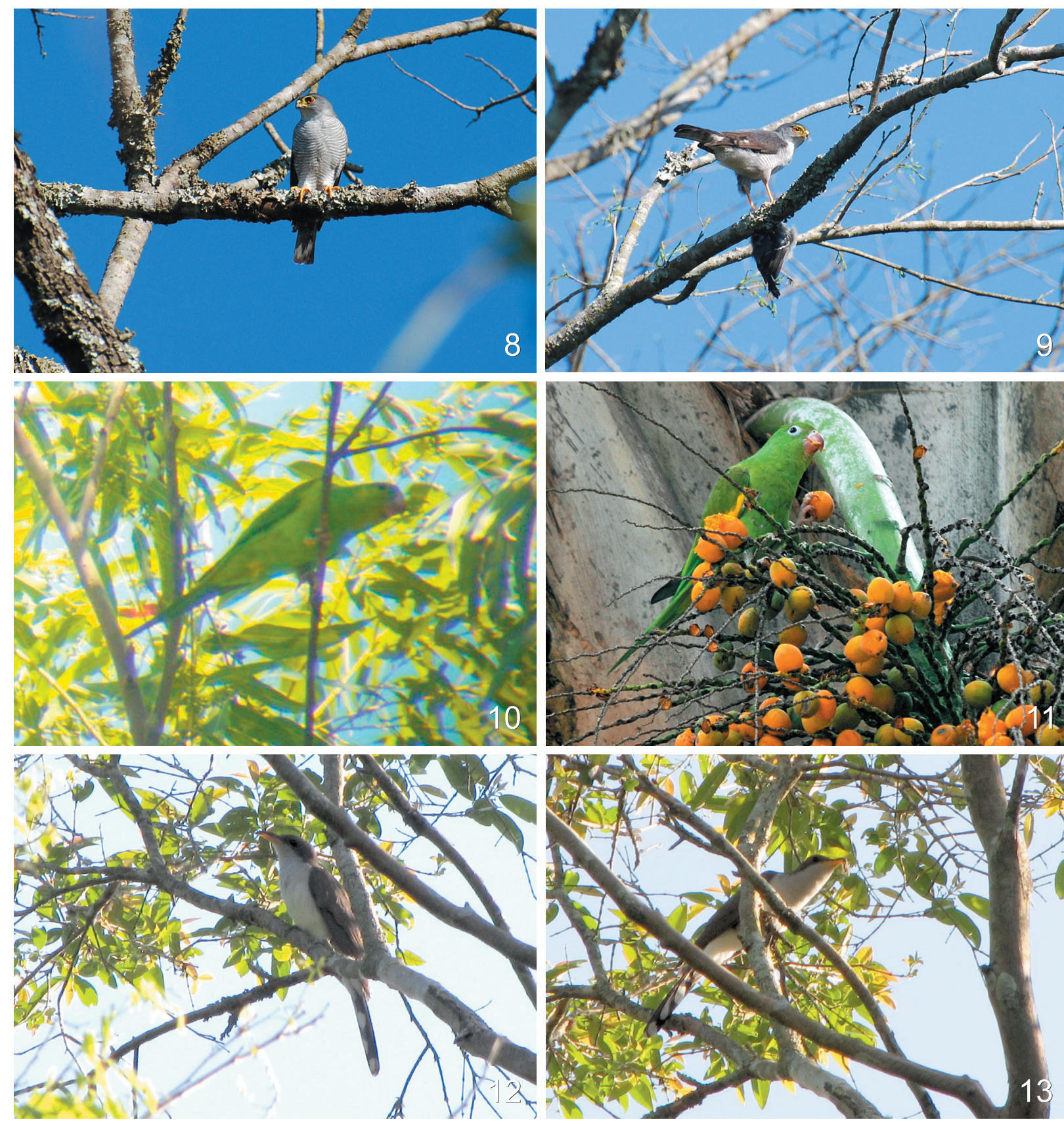

Figures 8-13. 8, 9, Accipiter superciliosus (Linnaeus, 1766), Turvo state park, Derrubadas, September 2010 (Caco Schwertner); 10, Brotogeris tirica (Gmelin, 1788), vicinity of Serra Geral biological reserve, Maquiné, February 2004 (G. Bencke); 11, Brotogeris chiriri (Vieillot, 1818), botanical garden, Porto Alegre, 19 November 2008 (Ricardo A. Ramos); 12, 13, Coccyzus euleri Cabanis, 1873, Turvo state park, October 2010 (G. Bencke). 
to note, however, that all the records above in which I was involved were in mature forest blocks $>500$ ha (much larger in most cases), though both in RGS and elsewhere this owl has been found within or around urban areas by others. In view of this, the status of (at least) Near Threatened seems appropriate, since today it may be mostly restricted to the interior and vicinity of large forest tracts in RGS. By comparison, the similar-sized Rustybarred Owl Strix hylophila Temminck, 1825, listed as Near Threatened at the global level (BIRDLifE INTERNATIONAL, 2010), is by far more common than the Tawny-browed Owl in highland woodlands of RGS, its known distribution within the state extending south into the south-eastern hills (Serra do Sudeste) and covering at least 21 halfdegree squares (data updated from BELTON, 1994), whilst that of P. koeniswaldiana does not pass beyond Rio Jacuí and presently covers only 7-8 such squares. As stated in BENCKE et al. (2003), a previous unsubstantiated report of the Spectacled Owl Pulsatrix perspicillata (Latham, 1790) for Turvo state park (AlbuQUERQUE, 1981) should be treated as doubtful given the now confirmed presence of $P$. koeniswaldiana there.

Spotted Bamboowren Psilorhamphus guttatus Atl. First reported by BENCKE \& KINDEL (1999) and BENCKE et al. (2000), the occurrence of this species in RGS is poorly documented (records summarised in BENCKE et al., 2003). A male-plumaged bird observed for over an hour in dense thickets of bamboo and lianas at the edge of disturbed foothill forest near Alto Rolante (29³9'12'S, $50^{\circ} 29^{\prime} 02$ ''W; $330 \mathrm{~m}$ ), on 14 November 2008, represents a new southernmost locality for the species (photographed by A. Becker - Fig. 16).

Pearly-vented Tody-Tyrant Hemitriccus margaritaceiventer. On 2 April 2007, I heard this todytyrant - with which I had previous experience in the state of São Paulo - in the dense riparian growth along Arroio

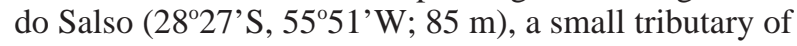
Rio Uruguai, some $25 \mathrm{~km}$ north-north-east of São Borja. Unfortunately my attempts to see the bird failed, mainly due to its elusive behaviour and remarkably inconspicuous movements. I later confirmed the identification by comparing my description and a taperecorded rendition of the bird's voice with sound recordings of H. margaritaceiventer presented in STRANECK (1990). Occurrence of this species in RGS is not surprising given that it ranges through the drainages of the Rio Paraná and Uruguai south to northern Buenos Aires province (DARRIEU \& CAMPERI, 1992; AZPIROZ, 2001; Bodrati et al., 2001; FitZPATRICK, 2004; DE LA PeÑa, 2006; Rocha, 2008). AzPIROZ \& MENÉNDEZ (2008) reported recent records from near Bella Unión, Uruguay, and speculated that the species may be present on the Brazilian side of Arroio Quaraí (Cuareim in Spanish), at the far western tip of RGS.

Gray-capped Tyrannulet Phyllomyias griseocapilla - Atl. Several records (April, May and November, 20032005) between $270-470 \mathrm{~m}$ in undisturbed forests and nearby anthropogenic habitats on the lower slopes of the Arroio Encantado valley (293' S, 50¹ $\left.11^{\prime} \mathrm{W}\right)$, Serra Geral biological reserve. On 14 April 2005, in secondary growth, high-pitched "PEEEEoo, peeuw it?" calls remarkably similar to those of the Rufous-thighed Kite Harpagus diodon (Temminck, 1823) but weaker drew my attention to a pair of full-grown fledglings with fleshy rictus, one of which received food from an adult. Voices heard from presumed adults on this and other occasions included a single, ca. 2-seconds-long rising whistle "puuuuiit?", as well as complex duets and the distinctive song, a series of 2-5 evenly spaced, clear "wheew" whistles given in the same pitch. Previously recorded south only to Planície Alta, Guabiruba, in north-eastern Santa Catarina (BARNETT et al., 2004), which lies about $300 \mathrm{~km}$ to the north.

Gray-crowned Tyrannulet Serpophaga griseicapilla. This cryptic, only recently named tyrannulet (STRANECK, 2007) was first reported for RGS in May 2001, when its presence was noted at two locations in the extreme west of the state (BENCKE et al., 2002). More recently, on 19-20 June 2003, a pair was observed along the south-western margin of Lagoa do Casamento, Palmares do Sul (30'22'57'S, 50'39'38' W), at the northernmost sector of Mostardas peninsula in the state's inland coastal plain. Further details on this record, the closest to the Atlantic coast so far, are given in BENCKE et al. (2007), whilst the audio recording documenting it appeared in Minns et al. (2010). Another record was on 24 July 2002 in São Donato biological reserve $\left(29^{\circ} 00^{\prime} \mathrm{S}, 56^{\circ} 11^{\prime} \mathrm{W}\right)$, where I saw two birds (one of which badly tape-recorded) on scattered espinilho Acacia caven (Leguminosae) shrubs fringing the southern margin of the São Donato marsh. These are the only published records in Brazil, all of which falling in the fall/early winter period.

Social Flycatcher Myiozetetes similis. The first RGS records of this highly vocal and open-country species date from the late 1970s and are from Turvo state park and vicinity, in the extreme north (AlbuQuerque, 1980). All subsequent records came from there or from near Iraí, about $60 \mathrm{~km}$ to the east (BELTON, 1994; PACHeCO \& FonseCA, 2002). On $1^{\text {st }}$ July 2005, two were in a cattle pasture with scattered eucalyptus and low bushes at the mouth of the Rio Forqueta valley, Maquiné (2931'34' $\mathrm{S}$, $50^{\circ} 14{ }^{\prime} 32^{\prime \prime} \mathrm{W} ; 150 \mathrm{~m}$ ). Birds perched high on trees and gave typical calls and duets (well known to me from previous experience in the north of RGS, as well as in the east and north-east of Brazil). This is the first record of the Social Flycatcher in the Atlantic slope of north-eastern RGS. NAKA \& RodRIGUES (2000) say it is only a summer resident further north at Ilha de Santa Catarina, Florianópolis, hitherto apparently the southernmost locality for the species along the Atlantic coast. Hence, my record from Maquiné is unusual in both its geographic and seasonal context, perhaps representing an instance of vagrancy or the result of a recent range expansion along densely settled areas of the littoral.

Short-crested Flycatcher Myiarchus ferox. Previously known with certainty in RGS from a single old specimen collected by Ernst Garbe at Itaqui, extreme west of the state, in August 1914 (PINTO, 1944; LANYON, 1978; Belton, 1985). Also listed without details for the municipalities of São Valentim (NAZZARI \& RESTELLO, 2005) and Jacutinga (Marchetto \& Restello, 2009), in the north, but until better evidence is furnished these records are perhaps best treated as uncertain. Another unconfirmed record comes from Fazenda Santa Rosa, Alegrete, in the Ibirapuitã environmental protection area (EFE et al., 2007). Two of three specimens of "Myiarchus ferox australis" from Bom Jesus listed by CAMARGO (1962), 
which are now in the Museu de Ciências Naturais of Fundação Zoobotânica do Rio Grande do Sul (MCN/ FZBRS), Porto Alegre, clearly represent Swainson's Flycatcher Myiarchus swainsoni Cabanis \& Heine, 1859 based on the identification criteria presented by LANYON (1978); the other one was probably lost (see BELTON, 1994). On 2 April 2007, I rediscovered the Short-crested Flycatcher along Arroio Pintado Grande (2905'28' S, $\left.56^{\circ} 24^{\prime} 05-16^{\prime \prime} \mathrm{W}\right), 15 \mathrm{~km}$ east-north-east of Itaqui. This locality is almost certainly within a few kilometers from where Garbe collected his specimen. Two single birds were calling about $300 \mathrm{~m}$ apart from exposed perches at the edge of low riparian vegetation, one of which was taperecorded at dusk for over half an hour (Fig. 4). Records above in conjunction with specimens reported from several localities in the adjacent Argentinean province of Corrientes (LANYON, 1978; DARRIEU \& CAMPERI, 1992) are evidence that $M$. ferox may be of regular occurrence in a limited area of the extreme west of RGS.

Grayish Saltator Saltator coerulescens. Surprisingly, there are no published records of this species for RGS, even though it occurs widely along Rio Uruguai in adjacent Argentina and Uruguay (e.g., Arballo, 1990; DARrieu \& CAMPERI, 1996; AZPIROZ, 2001; Claramunt \& Cuello, 2004; de la Peña, 2006). At Espinilho state park, in the western tip of the state, I observed and tape-recorded (Figs 5,6) a family of four birds on 7 February 2002, in the shrubby riparian vegetation of Arroio Quaraí-Chico (30¹1'40' S, $\left.57^{\circ} 29^{\prime} 16^{\prime \prime} \mathrm{W}\right)$. Two others tape-recorded on the same morning were about $700 \mathrm{~m}$ away in espinilho parkland. In addition, Bret Whitney obtained a photograph of a Grayish Saltator in the park in January 2008 (Fig. 17). At this site, $S$. coerulescens is syntopic with the congeners Green-winged S. similis d'Orbigny \& Lafresnaye, 1837 and Golden-billed Saltator S. aurantiirostris Vieillot, 1817. I and Mauricio da S. Pereira found Grayish Saltators also about $6 \mathrm{~km}$ east-north-east of Uruguaiana at the point where highway BR-472 crosses the Arroio Imbaá (29 45'00' S, 56 59'25' W). At least five birds were at this site on 21 March 2007, including two pairs separated by $300 \mathrm{~m}$ plus a seemingly unpaired individual. Birds were feeding on fruits of a spiny shrub, Celtis sp. (Cannabaceae). Further to the north, I found $S$. coerulescens in the low riparian woodland skirting the southern margin of the São Donato marsh $\left(29^{\circ} 00^{\prime} 48^{\prime}\right.$ ' $\mathrm{S}$, $\left.56^{\circ} 11^{\prime} 19^{\prime \prime} \mathrm{W}\right)$, where an isolated pair was heard and subsequently tape-recorded from the BR-472 highway on 21 March 2002 (seen there again on 25 April 2002). The species was also noticed by Marilise M. Krügel and Daniel T. Gressler near Roque Gonzales (28 $08^{\prime} \mathrm{S}$, $\left.55^{\circ} 01^{\prime} \mathrm{W}\right)$, in the Rio Ijuí drainage, in September-December 2004 (M. M. Krügel, pers. comm.). In conjunction, records above suggest that Grayish Saltators may be expected almost everywhere in areas with suitable habitat within a few kilometers of Rio Uruguai in the western and northwestern sectors of the state, along the Argentinean border.

Olive-green Tanager Orthogonys chloricterus - Atl. One specimen (MCN 2730, female?, weight 39.5 g, skull $100 \%$ ossified, no moult) was collected with C. E. Agne around our camp at the Arroio Encantado valley (29³6’38'S, 50¹1'26”'W), Serra Geral biological reserve, on 28 May 2003. Recorded earlier on the same day at $29^{\circ} 36$ '29' $\mathrm{S}, 50^{\circ} 12^{\prime} 01^{\prime \prime} \mathrm{W}$ and found again outside the reserve on the $31^{\text {st }}$ at $29^{\circ} 36^{\prime} 24^{\prime \prime} \mathrm{S}, 50^{\circ} 12^{\prime} 16^{\prime \prime} \mathrm{W}$. On all these occasions, birds were feeding on fruits of cultivated tangerines Citrus reticulata (Rutaceae) in groups of up to 12. Additionally, a noisy flock of at least five birds was in the canopy of primary forest in the same valley on 15 December 2004. All records were between 230-400 m elevation. Observations above represent a range extension of about $250 \mathrm{~km}$ from Caldas da Imperatriz and Ilha de Santa Catarina, previously the southernmost known localities for this Atlantic forest endemic (Albuquerque \& Brüggemann, 1996; Piacentini et al., 2006).

Rufous-headed Tanager Hemithraupis ruficapilla - Atl. First recorded in RGS on 30 October 1998 (BENCKE, 2001), when two males were spotted in a mixed-species flock with Red-necked Tanager Tangara cyanocephala (Statius Muller, 1776) and Golden-rumped Euphonia Euphonia cyanocephala (Vieillot, 1818), in foothill evergreen forest at the Rio Três Forquilhas valley, Itati. Since then I have found it at three additional sites in north-eastern RGS. At Serra Geral biological reserve and surroundings, Rufous-headed Tanagers were in disturbed forests and second growth on the lower slopes of the Arroio Encantado and Ligeiro (293' $34^{\prime}$ S, 50 $13^{\circ} \mathrm{W}$ ) valleys, on 4 November 2003 and 27 September 2005, respectively. A photograph was obtained (Fig. 18), providing the first tangible evidence for the species in RGS. Birds at Arroio Ligeiro were consuming fruits of Myrsine coriacea (Myrsinaceae) in company of Green-headed Tanagers Tangara seledon (Statius Muller, 1776), Blue Dacnis Dacnis cayana (Linnaeus, 1766), and Ruby-crowned Tanager Tachyphonus coronatus (Vieillot, 1822), or visiting flowers of exotic Eucalyptus sp. for nectar. One male observed at this site had the hood deep chestnut, darker on forehead and around eyes, suggesting an intermediate between this species and the closely related Guira Tanager Hemithraupis guira (Linnaeus, 1766) (see ZIMMER, 1947), which is fairly common further inland in forested areas of the northern half of the state. To my knowledge, however, the two have yet to be found syntopically in RGS. More recently, I observed a pair of $H$. ruficapilla in a patch of primary lowland coastal forest known as Mata do Baptista (29²3'03''S, 4950'20'W), just past the main access to Dom Pedro de Alcântara (formerly Colônia São Pedro), on 30 September 2008. On 10 June 2009, another pair was in remaining coastal forests west of Lagoa do Jacaré (2919'33' S, 4951'03'W W), Torres, foraging in the canopy along with a couple of $D$. cayana. Records above are the southernmost for the species and span altitudinally from near sea level to about $335 \mathrm{~m}$. The Rufous-headed Tanager remains unreported from adjacent areas of Santa Catarina, where it is known south only to about $27^{\circ} 45^{\prime} \mathrm{S}$ (RosÁRIO, 1996; NAKA \& RoDRIGUES, 2000).

Lined Seedeater Sporophila lineola. Cleodir Mansan called my attention to the appearance of a small black and white seedeater with distinct white marks on head at his second home in the outskirts of Maquiné (2941'34'S, 50¹1'25' W), northern coastal plain of RGS, in November 2004. On 17 January 2005, shortly after arriving there at 15:45 h, I located an adult male Lined Seedeater singing atop a tree on the left bank of Rio 
Água Parada. Throughout the afternoon, this male moved along a section of about $90 \mathrm{~m}$ of the river, often in company of a female-plumaged bird, which he apparently followed around when not singing. Another territorial male and at least one additional female or immature were detected within $100 \mathrm{~m}$ of this point. A motorboat search through a section of $2.3 \mathrm{~km}$ of Rio Água Parada plus $10.1 \mathrm{~km}$ of the adjacent Rio Maquiné revealed a third adult male singing along the former ( $c a .400 \mathrm{~m}$ upriver from the first male detected) but no birds and almost no suitable habitat along the course of the latter. Differently from the Rio Maquiné, the Água Parada is a narrow, slow- flowing river plenty of dense mats of floating grasses in the summer. Tall grasses also occur along its damp margins, where birds were seen feeding on seeds of Echinochloa polystachya (Poaceae). Birds also fed on seeds of Echinochloa crus-pavonis and Paspalum sp. grasses. I visited the area again on 11 April and 30 June 2005, 17 February 2006, 30 October 2008, and 26 February 2010 , and observed the species only in austral summer and fall. In 2006 only an immature was observed, but at least two males were around in 2010 (Figs 7, 19), with another singing bird detected about $1 \mathrm{~km}$ to the southeast at $29^{\circ} 41^{\prime} 48^{\prime \prime} \mathrm{S}, 50^{\circ} 10^{\prime} 56^{\prime \prime} \mathrm{W}$. Unsystematic but
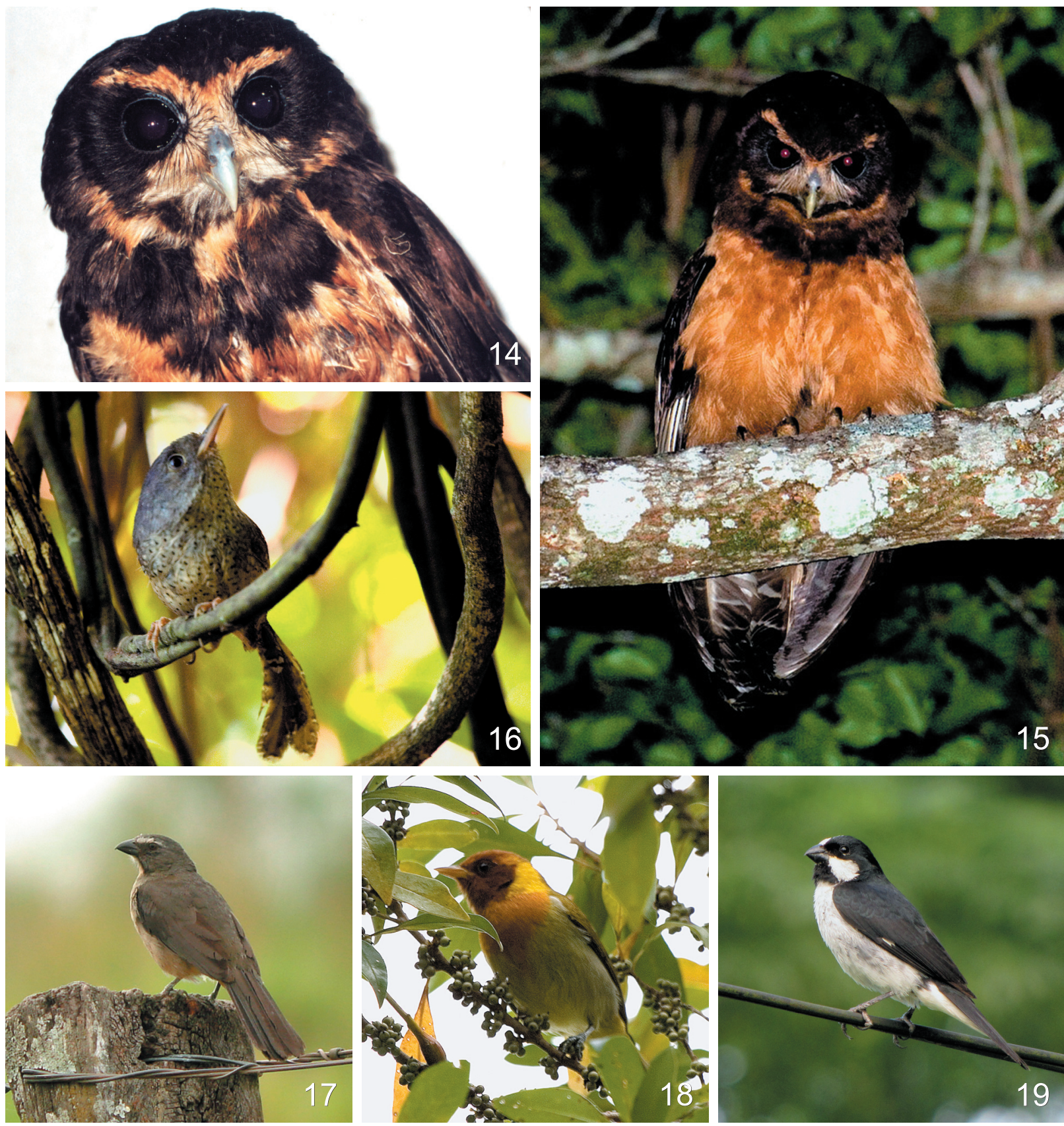

Figures 14-19. 14, 15, Pulsatrix koeniswaldiana (Bertoni \& Bertoni, 1901) at Salto do Jacuí (left), 14 May 1998 (Maria L. M. Alves) and Turvo state park, Derrubadas (right), 9 October 2004 (Adriano Becker); 16, male Psilorhamphus guttatus (Ménétriès, 1835), Alto Rolante, November 2008 (A. Becker); 17, Saltator coerulescens Vieillot, 1817, Espinilho state park, Barra do Quaraí, January 2008 (Bret Whitney); 18, male Hemithraupis ruficapilla (Vieillot, 1818), Serra Geral biological reserve, Maquiné, September 2005 (A. Becker); 19 , male Sporophila lineola (Linnaeus, 1758), Maquiné outskirts, 26 February 2010 (G. Bencke). 
recurrent observations by $\mathrm{C}$. Mansan indicate the species has been an annual summer visitor to the area from about November through mid-April (though in 2010 birds had apparently already departed by early March). This agrees with published data on the seasonal occurrence of the Lined Seedeater in south-eastern South America (e.g., Hayes et al., 1994; Silva, 1995; D’angelo Neto \& VASCONCELOS, 2007). Although RGS is outside the known range of the species, the simultaneous observation of at least five different individuals in a single year and the consistent migratory behaviour exhibited by the birds over the years make it unlikely that the records above refer to escapees. Instead, when interpreted in conjunction with the recent reports for Santa Catarina and Misiones (CARrano et al., 2002; Areta \& Almirón, 2009), they constitute additional evidence that this mainly tropical seedeater is spreading southward in southeastern South America, possibly as a result of large-scale alterations in vegetation cover, perhaps compounded by the effects of recent human-induced climate change producing shorter, milder winters (see below).

\section{CONCLUDING REMARKS}

Atlantic forest endemics: biogeographical and conservation implications. SILVA et al. (2004) applied the method of parsimony analysis of endemicity to identify areas of endemism for passerine birds within the Atlantic forest biogeographical region of south-eastern South America. In this method, the areas (geographical units) are equivalent to taxa and species are equivalent to characters in a phylogenetic analysis. Boundaries of the resulting areas of endemism are based on the percentage of overlap amongst the endemic species' ranges. One of the four basal areas identified by SiLva et al. (2004), the Serra do Mar, was defined by two endemic species, Orthogonys chloricterus and Dacnis nigripes Pelzeln, 1856 , which were uniquely shared by nine of a total of 24 well-sampled and representative one-degree quadrats chosen as the geographical units for the analysis. These nine quadrats are distributed in the states of Espírito Santo, Rio de Janeiro, São Paulo, Paraná and Santa Catarina. Although no RGS region could belong in this biogeographical "clade" of quadrats because of the absence of $D$. nigripes, the discovery of $O$. chloricterus in the north-east of the state qualifies this region for inclusion in the zone of $50 \%$ endemic species range overlap of the Serra do Mar area (mapped as extending south only to eastern Santa Catarina by Silva et al., 2004). In effect, nearly half of the endemic passerines listed by Silva et al. (2004) for their Serra do Mar area (59 of 120) are known to occur in north-eastern RGS, including nine species discovered in the state only in the past 15 years (six of which treated here).

When all endemic species are considered (i.e., both passerines and non-passerines), another aspect becomes apparent. Of the approximately 223 bird species endemic to the Atlantic forest region (number based on PARKER et al., 1996, BRoOKs et al., 1999, and BencKe et al., 2006, with addition of some recent taxonomic splits), no less than 52\% (116) occur in RGS, where the Atlantic forest fades out into the temperate Pampas or Río de la Plata grasslands and reaches its southernmost range. In contrast, the concentration of endemic bird species at the opposite (i.e., northern) end of this biogeographical region is considerably lower. For example, two of the northernmost states where the Atlantic forest is represented (Paraíba and Ceará) harbour just 7.5\% and $10 \%$ of the endemic species, respectively, whilst Pernambuco has only 18\% (CEMAVE, 2000; GIRÃO E SILVA \& AlbANO, 2002; FARIAS et al., 2008; no reliable bird lists available for other states). This asymmetry in the proportion of endemic species at the opposite ends of the Atlantic forest is probably related to a complex combination of biogeographical and landscape features, including the influence of adjacent forest biomes on the avifauna and the effects of area, continentality, and differing altitudinal profiles. Apart from its biogeographical significance, this asymmetric distribution of bird endemism may be relevant from a conservation viewpoint as well. However, to my knowledge, its implications for the long-term maintenance of the highly diverse and endemic Atlantic forest avifauna have not yet been adequately evaluated, particularly in light of the forecast changes in global climate, which may cause substantial shifts or reductions in present geographic distributions, thus making remaining forests in southern latitudes relatively more and more important for a crescent number of species. As a result, evergreen and seasonal forests of extreme southern Brazil tend to be regarded as relatively unimportant or given low priority in biome-level conservation planning and action initiatives, particularly those emphasizing endemic species richness or number of threatened birds as priority indicators, which invariably drive attention towards areas in south-eastern Brazil, where most of the endemic birds concentrate, or to the Atlantic forest remnants in northeastern Brazil, where endemic species are few but face an extremely high risk (HARRIS et al., 2005; PINTO et al., 2006).

Newly colonizing and range-expanding birds. The majority of the new records reported above undoubtedly represent species that have as yet been overlooked in RGS, either because they occur only marginally and hence have very small ranges in the state (e.g., Accipiter superciliosus, Brotogeris tirica and Phyllomyias griseocapilla) or because they are sparsely distributed near the southern edge of their geographical ranges (e.g., Ixobrychus exilis and perhaps Pulsatrix koeniswaldiana). However, at least the records of Sporophila lineola and Myiozetetes similis seem most likely to be a consequence of recent range expansions by northern species into the state. It is also remarkable that such a conspicuous species as Saltator coerulescens passed unnoticed until recently, particularly in a locality so well surveyed in the past as the Espinilho state park (see Belton 1984, 1985). Other examples of tropical species that are or may equally be expanding in RGS include the Pale-breasted Thrush Turdus leucomelas Vieillot, 1818 (BENCKE \& GrILlo, 1995), the Scaled Dove Columbina squammata (Lesson, 1831) (SILVA, 2006), the White Woodpecker Melanerpes candidus (Otto, 1796) (BENCKE et al., 2007), the estuarine herons Nyctanassa violacea (Linnaeus, 1758) (GIANUCA, 2007) and Egretta caerulea (Linnaeus, 1758) (GIANUCA et al., 2008), and the 
recently recorded White-bellied Seedeater Sporophila leucoptera (Vieillot, 1817) (BECKER, 2009) and Planalto Hermit Phaethornis pretrei (Lesson \& Delattre, 1839) (DAmiani, 2009), besides the Red-rumped Cacique Cacicus haemorrhous (G. Bencke, unpublished data). These seemingly recent changes in northerly species' distributions into or within the borders of RGS are likely to be related to the significant positive trends in surface air temperature (largely due to higher minimum temperatures) detected for southern Brazil over the last four to five decades (MARQues et al., 2005; VINCENT et $a l ., 2005$; Silveira \& Gan, 2006; MARENGo \& CAMARGO, 2008), although land-use alteration may have played an important role as well. Similar distributional shifts linked to warmer temperatures have been documented for several species of birds in other parts of the world (Brommer, 2004; CRICK, 2004; RAPPOLE et al., 2007).

Acknowledgments. I thank Giovanni N. Maurício, Adriano Becker, Jan Karel F. Mähler Jr, Andreas Kindel, Mauricio da S. Pereira, Carlos Eduardo Agne, Ismael Franz, Cristian M. Joenck, Cleodir Mansan, Paulo Fenalti, Caco Schwertner and Tomaz V. Aguzzoli for help and companionship in the field. I am also indebted to G. N. Maurício, Marilise M. Krügel, Daniel T. Gressler and Bret Whitney for sharing their unpublished data, and to the latter, A. Becker, C. Schwertner, Ricardo A. Ramos and Maria Lúcia M. Alves for use of their photographs. Juan I. Areta, G. N. Maurício, C. Mansan, Adrián Azpiroz, J. K. F. Mähler Jr, C. E. Agne, Fábio Jacomassa and Eduardo S. Borsato provided critical references and/or information. Maria de Lourdes A. A. de Oliveira and Ilsi Boldrini identified the grasses used by S. lineola. Arlete Pasqualetto produced the map. Rafael A. Dias and G. N. Maurício kindly reviewed the text. Fieldwork at Turvo, Espigão Alto and Rondinha state parks in 2000 was conducted under the RS-Rural project run by the state government with funds from The World Bank. Research at the Lagoa do Morro do Forno/Lagoa do Jacaré complex was supported by Fundação $\mathrm{O}$ Boticário de Proteção à Natureza (Grant 0755/20072) and was part of a joint Centro de Ecologia-UFRGS, NGO Curicaca and Fundação Zoobotânica do Rio Grande do Sul project. Observations at Serra Geral biological reserve were part of the project Conservação da Mata Atlântica no Rio Grande do Sul, financed by the KfW Entwicklungsbank. Finally, I wish to acknowledge the state agency for protected areas (DUC/DEFAP) and the administrators of the protected areas visited, for permission to work there.

\section{REFERENCES}

Agne, C. E. 2004. Primeiro registro do socoí-vermelho, Ixobrychus exilis (Gmelin, 1789) para o Rio Grande do Sul. Atualidades Ornitológicas (120): 12

Albuquerque, E. P. 1980. Ocorrência de duas novas aves para o Estado do Rio Grande do Sul, Brasil: Myiozetetes similis (Aves, Tyrannidae) e Claravis pretiosa (Aves, Columbidae). Roessleria 3(2):189-194.

1981. Lista preliminar das aves observadas no Parque Florestal Estadual do Turvo, Tenente Portela, Rio Grande do Sul, Brasil. Roessleria 4(1):107-122.

Albuguerque, J. L. B. \& Brüggemann, F. M. 1996. A avifauna do Parque Estadual da Serra do Tabuleiro, Santa Catarina, Brasil e as implicações para sua conservação. Acta Biologica Leopoldensia 18(1):47-68.

Arballo, E. 1990. Nuevos registros para avifauna uruguaya. El Hornero 13:179-187.

Areta, J. I. \& Almirón, D. 2009. Comentarios sobre la presencia, voces y alimentación del Corbatita Overo Sporophila lineola a orillas de los ríos Paraná e Iguazú en Misiones, Argentina. Cotinga (31):59-62.

AzPIRoz, A. 2001. Aves del Uruguay. Lista e introducción a su biología y conservación. Montevideo, Aves Uruguay, GUPECA. $104 \mathrm{p}$.
AzPiroz, A. B. \& MenÉndez, J. L. 2008. Three new species and novel distributional data for birds in Uruguay. Bulletin of the British Ornithologists' Club 128(1):38-56.

Barnett, J. M.; Minns, J.; Kirwan, G. M. \& Remold, H. 2004 Informações adicionais sobre as aves dos estados do Paraná, Santa Catarina e Rio Grande do Sul. Ararajuba 12(1):55-58.

Behrstock, R. A. 1996. Voices of Stripe-backed Bittern Ixobrychus involucris, Least Bittern I. exilis, and Zigzag Heron Zebrilus undulatus, with notes on distribution. Cotinga (5):55-61.

Becker, R. G. 2009. Primeiro registro de Sporophila leucoptera (Emberizidae) no Rio Grande do Sul, Brasil. Revista Brasileira de Ornitologia 17(3-4):213-216.

Belton, W. 1984. Birds of Rio Grande do Sul, Brazil. Part 1: Rheidae through Furnariidae. Bulletin of the American Museum of Natural History 178(4):369-636.

1985. Birds of Rio Grande do Sul, Brazil. Part 2: Formicariidae through Corvidae. Bulletin of the American Museum of Natural History 180(1):1-242.

1994. Aves do Rio Grande do Sul, distribuição e biologia. São Leopoldo, Unisinos. 584p.

Bencke, G. A. 2001. Lista de referência das aves do Rio Grande do Sul. Porto Alegre, Fundação Zoobotânica do Rio Grande do Sul (Publicações Avulsas FZB, 10). 102p.

Bencke, G. A.; Burger, M. I.; Dotto, J. C. P.; Guadagnin, D. L.; Leite, T. O. \& Menegheti, J. O. 2007. Aves. In: Becker, F. G.; Ramos, R. A. \& Moura, L. A. orgs. Biodiversidade. Regiões da Lagoa do Casamento e dos Butiazais de Tapes, Planície Costeira do Rio Grande do Sul. Brasília, Ministério do Meio Ambiente. p.316-355.

Bencke, G. A.; Fontana, C. S. \& Mendonça-Lima, A. 2002. Registro de dois novos passeriformes para o Brasil: Serpophaga griseiceps (Tyrannidae) e Asthenes pyrrholeuca (Furnariidae). Ararajuba 10(2):266-269.

Bencke, G. A.; Fontana, C. S.; Dias, R. A.; Maurício, G. N. \& MäHler JR, J. K. F. 2003. Aves. In: Fontana, C. S.; Bencke, G. A \& REIS, R. E. eds. Livro vermelho da fauna ameaçada de extinção no Rio Grande do Sul. Porto Alegre, Edipucrs. p. 189-479.

Bencke, G. A. \& Grillo, H. C. Z. 1995. Range expansion of the Pale-breasted Thrush Turdus leucomelas (Aves, Turdidae) in Rio Grande do Sul, Brazil. Iheringia, Série Zoologia, (79):175176

Bencke, G. A.; Jardim, M. M. A.; Borges-Martins, M. \& Zank, C. 2009. Composição e padrões de distribuição da fauna de tetrápodes recentes do Rio Grande do Sul, Brasil. In: Ribeiro, A. M.; Bauermann, S. G. \& Scherer, C. S. eds. Quaternário do Rio Grande do Sul: integrando conhecimentos. Porto Alegre, Sociedade Brasileira de Paleontologia (Série Monografias). p.123-142.

Bencke, G. A. \& Kindel, A. 1999. Bird counts along an altitudinal gradient of Atlantic forest in northeastern Rio Grande do Sul, Brazil. Ararajuba 7(2):91-107.

Bencke, G. A.; Kindel, A. \& MäHLER JR, J. K. F. 2000. Adições à avifauna de Mata Atlântica do Rio Grande do Sul. In: Alves, M. A. S.; Cardoso da Silva, J. M.; Sluys, M. V.; Bergallo, H. G. \& Rocha, C. F. D. orgs. A Ornitologia no Brasil, pesquisa atual e perspectivas. Rio de Janeiro, EdUERJ. p.317-323

Bencke, G. A.; Maurício, G. N.; Develey, P. E. \& Goerck, J. M. orgs. 2006. Áreas importantes para a Conservação de Aves no Brasil - Parte I - Estados do Domínio Mata Atlântica. São Paulo, Save Brasil. 494p.

Bernardi, I. P.; Teixeira, E. M. \& Jacomassa, F. A. F. 2008 Registros relevantes da avifauna do Alto Uruguai, Rio Grande do Sul, Brasil. Biociências 16(2):134-137.

BirdLife International. 2010. Species factsheet: Strix hylophila. Available at: <http://www.birdlife.org $>$. Access on: 30/10/ 2010.

Bodrati, A. 2005. Nuevos aportes a la distribución de algunas especies de aves argentinas. Nuestras Aves (50):30-33.

Bodrati, A.; Bodrati, G. \& Fernández, H. 2001. Notas sobre la avifauna del norte de la Provincia de Buenos Aires, Argentina. Nuestras Aves (41):17-21.

Bodrati, A.; Cockle, K.; Matuchaka, V. \& Maders, C. 2005. Reserva de la Biósfera Yabotí. In: Di Giacomo, A. S. ed. Áreas importantes para la conservación de las aves em Argentina. Sítios prioritarios para la conservación de la 
biodiversidad. Buenos Aires, Aves Argentinas/Asociación Ornitológica del Plata (Temas de Naturaleza y Conservación, 5). p.300-302.

BRommer, J. E. 2004. The range margins of northern birds change polewards. Annales Zoologici Fennici 41:391-397.

Brooks, T.; Tobias, J. \& Balmford, A. 1999. Deforestation and bird extinctions in the Atlantic forest. Animal Conservation 2:211-222.

Camargo, O. R. 1962. Aves sul-riograndenses do Museu de Caça e Pesca. Pesquisas, Série Zoologia, (14):1-67.

Carrano, E.; Ribas, C. F. \& Müller, J. A. 2002. Primeiros registros do bigodinho Sporophila lineola para Santa Catarina. Atualidades Ornitológicas (108): 12 .

CEMAVE (Centro Nacional de Pesquisa para Conservação das Aves Silvestres). 2000. Lista das aves da Paraíba. João Pessoa, IBAMA, SUPES/PB. Available on: <http:// www4.icmbio.gov.br/cemave>. Access on: October 2010. 10p.

Claramunt, S. \& Cuello, J. P. 2004. Diversidad de la Biota Uruguaya - Aves. Anales Museo Nacional de Historia Natural y Antropologia (2 $2^{\text {a Serie) }}$ 10(6):1-76.

Crick, H. Q. P. 2004. The impact of climate change on birds. Ibis 146(Suppl.1):48-56.

Damiani, R. V. 2009. Primeiro registro de Phaethornis pretrei (Aves, Trochilidae) para o Rio Grande do Sul, Brasil. Biotemas 22(2): 199-202.

D’Angelo Neto, S. \& Vasconcelos, M. F. 2007. Distribuição geográfica de duas populações migratórias do bidoginho, Sporophila lineola (Linnaeus, 1758), em Minas Gerais, Brasil. Ornithologia 2(1):25-27.

Darrieu, C. A. \& CAmperi, A. R. 1992. Estudio de una colección de aves de Corrientes. III. (Tyrannidae). El Hornero 13:219-224. 1996. Estudio de una colección de aves de Corrientes (Emberizidae y Fringillidae). Neotrópica 42(107/108):69-75.

DE LA PeÑA, M. R. 2006. Lista y distribución de las aves de Santa Fe y Entre Ríos. Buenos Aires, L.O.L.A. 137p.

Efe, M. A.; Mohr, L. V. \& Bugoni, L. 2001. Guia ilustrado das aves dos parques de Porto Alegre. Porto Alegre, Proaves/ SMAM/Copesul/Cemave. 144p.

Efe, M. A.; Oliveira, A. C.; Koch, M.; Flores, J. M. \& Scherer, S. B. 2007. Avifauna da Área de Proteção Ambiental do Ibirapuitã, Rio Grande do Sul, Brasil. Ornithologia 2(1):14-24.

Farias, G. B.; Pereira, G. A. \& Girão e Silva, W. A. 2008. Lista das aves de Pernambuco. Recife, Observadores de Aves de Pernambuco. 40p.

FitzPATRick, J. W. 2004. Family Tyrannidae (tyrant-flycatchers). In: Del Hoyo, J.; Elliott, A. \& Christie, D. A. eds. Handbook of the birds of the world, vol. 9. Cotingas to pipits and wagtails. Barcelona, Lynx Edicions. p.170-462.

FontanA, C. S. 2005. A ornitofauna em Porto Alegre no século XX: status de ocorrência e conservação. Comunicações do Museu de Ciências e Tecnologia da PUCRS 18(2):161-206.

Fontana, C. S.; Bencke, G. A. \& Reis, R. E. orgs. 2003. Livro vermelho da fauna ameaçada de extinção no Rio Grande do Sul. Porto Alegre, EDIPUCRS. 632p.

Fontana, C. S.; Rovedder, C. E.; Repenning, M. \& Gonçalves, M. L. 2008. Estado atual do conhecimento e conservação da avifauna dos Campos de Cima da Serra do sul do Brasil, Rio Grande do Sul e Santa Catarina. Revista Brasileira de Ornitologia 16(4):281-307.

Gianuca, D. 2007. Ocorrência sazonal e reprodução do socócaranguejeiro Nyctanassa violacea no estuário da Lagoa dos Patos, novo limite sul da sua distribuição geográfica. Revista Brasileira de Ornitologia 15(3):464-467.

Gianuca, D.; Quintela, F. M.; Barros, J. A.; Gomes Jr, A. \& Gianuca, N. M. 2008. Ocorrência regular da garça-azul Egretta caerulea (Ciconiiformes, Ardeidae) no estuário da Lagoa dos Patos, Rio Grande do Sul, Brasil. Pan-American Journal of Aquatic Sciences 3(3):328-334.

Girão e Silva, W. A. \& Albano, C. G. 2002. Lista remissiva da avifauna cearense. Recife, Observadores de Aves de Pernambuco. Available on: <http://www.oap.org.br/ listaCE.htm>. Access on: September 2010.

Grantsau, R. 2002. Primeiro registro documentado de Phrygilus fruticeti (Kittlitz, 1833) para o Brasil (Rio Grande do Sul). Ararajuba 10(2):262-263.
Harris, G. M.; Jenkins, C. N. \& Pimm, S. L. 2005. Refining biodiversity conservation priorities. Conservation Biology 19(6): 1957-1968.

Hayes, F. E.; Scharf, P. A. \& Ridgely, R. S. 1994. Austral bird migrants in Paraguay. Condor 96(1):83-97.

KRÜGEL, M. M. 2003. Registro documentado de Chondrohierax uncinatus (Temminck, 1822) (Falconiformes: Accipitridae) para o Rio Grande do Sul. Ararajuba 11(1):83-84.

Kushlan, J. A. \& Hancock, J. A. 2005. The herons. Oxford, Oxford University Press. 456p.

LANYon, W. E. 1978. Revision of the Myiarchus flycatchers of South America. Bulletin of the American Museum of Natural History 161(4):427-628.

Marchetto, C. \& Restello, R. M. 2009. Composição da avifauna do Parque Municipal Ernesto Vitório Menin, Jacutinga/RS. Perspectiva 33(121):111-121.

Marengo, J. A. \& Camargo, C. C. 2008. Surface air temperature trends in Southern Brazil for 1960-2002. International Journal of Climatology 28(7):893-904.

Marques, J. R. Q.; Steinmetz, S.; Diniz, G.; Siqueira, O. J. W.; Wrege, M. S.; Herter, F. G. \& Reisser JR., C. 2005. Aumento da temperatura mínima do ar no Rio Grande do Sul, sua relação com o aquecimento global e possíveis impactos no arroz irrigado. In: CONGRESSO BRASILEIRO DE ARROZ IRRIGADO, 4. Anais... Santa Maria, Sociedade Sul-Brasileira de Arroz Irrigado. p.224-226.

Maurício, G. N. 2005. Taxonomy of southern populations in the Scytalopus speluncae group, with description of a new species and remarks on the systematics and biogeography of the complex (Passeriformes: Rhinocryptidae). Ararajuba 13(1):7-28.

MAYER, S. 2000. Birds of Bolivia 2.0. CD-ROM. Westernieland, The Netherlands, Bird Songs International BV.

Militello, E. R. 2005. Presencia y alimentación del esparvero chico (Accipiter superciliosus) en el Parque Nacional Iguazú, Misiones, Argentina. Nuestras Aves (49):23-24.

Minns, J.; Buzzetti, D.; Albano, C.; Grosset, A.; Whittaker, A. \& Parrini, R. 2010. Aves do Brasil, vozes e fotografias. Vol. 1 - Floresta Atlântica, Cerrado, Caatinga, Pantanal, Campos Sulinos e Costa. Versão 1.0 (DVD-ROM). Vinhedo, Avis Brasilis Editora.

Naka, L. N. \& Rodrigues, M. 2000. As aves da Ilha de Santa Catarina. Florianópolis, UFSC. 294p.

Narosky, T. \& Yzurieta, D. 2003. Guia para la identificación de las aves de Argentina y Uruguay. 15. ed. Buenos Aires, Vazquez Mazzini Editores. 346p.

NazZari, J. \& Restello, R. M. 2005. Avifauna do município de São Valentim - RS: riqueza e guildas tróficas. Perspectiva 29(105):53-60.

Pacheco, J. F. \& Fonseca, P. S. M. 2002. Resultados de uma excursão ornitológica a determinadas áreas dos estados de São Paulo, Santa Catarina e Rio Grande do Sul em janeiro, 1990. Atualidades Ornitológicas (106):3-5.

Parker III, T. A.; Stotz, D. F. \& FitzPatrick, J. W. 1996. Ecological and distributional databases. In: Stotz, D. F.; FitzPatrick, J. W.; Parker III, T. A. \& Moskovitz, D. K. Neotropical birds: ecology and conservation. Chicago, University of Chicago. p. $118-436$.

Payne, R. B. 2005. The cuckoos. Oxford, Oxford University. $644 \mathrm{p}$.

Piacentini, V. Q.; Ghizoni-Jr, I. R.; Azevedo, M. A. G. \& Kirwan, G. M. 2006. Sobre a distribuição de aves em Santa Catarina, Brasil, parte I: registros relevantes para o estado ou inéditos para a Ilha de Santa Catarina. Cotinga (26):25-31.

Pinto, L. P.; Bedê, L.; Paese, A.; Fonseca, M.; Paglia, A. \& Lamas, I. 2006. Mata Atlântica brasileira: Os desafios para conservação da biodiversidade de um hotspot mundial. In: Rocha, C. F. D.; Bergallo, H. G.; Sluys, M. V. \& Alves, M. A. S. orgs. Biologia da conservação: Essências. São Carlos, Rima. p.69-96.

Pinto, O. M. O. 1944. Catálogo das aves do Brasil. $2^{\text {a }}$ Parte. São Paulo, Departamento de Zoologia, Secretaria da Agricultura, Indústria e Comércio. 446p.

Rappole, J. H.; Blacklock, G. W. \& Norwine, J. 2007. Apparent rapid range change in South Texas birds: Response to climate 
change? In: NoRwine, J. \& JoHn, K. eds. The changing climate of South Texas 1900-2100: Problems and prospects; impacts and implications. Kingsville, Texas A\&M University. p.133-145.

Repenning, M. \& Fontana, C. S. 2008. Novos registros de aves raras e/ou ameaçadas de extinção na Campanha do sudoeste do Rio Grande do Sul, Brasil. Revista Brasileira de Ornitologia 16(1):58-63.

Rосна, G. 2008. Aves del Uruguay. El país de los pájaros pintados. Montevideo, Banda Oriental. v. 3, 145p.

RosÁrio, L. A. 1996. As aves em Santa Catarina: distribuição geográfica e meio ambiente. Florianópolis, FATMA. 326p.

SeIPKE, S. H. \& CabanNe, G. S. 2002. Rapaces observadas en un área selvática de San Pedro, Misiones, Argentina. Ornitologia Neotropical 13:273-282.

Silva, J. M. C. 1995. Seasonal distribution of the Lined Seedeater Sporophila lineola. Bulletin of the British Ornithologists' Club 115:14-21.

Silva, J. M. C.; Sousa, M. C. \& Castelletti, C. H. M. 2004. Areas of endemism for passerine birds in the Atlantic forest, South America. Global Ecology and Biogeography 13:85-92.

SiLVA, R. R. V. 2006. Primeiro registro documentado de Columbina squammata (Columbidae) para o Rio Grande do Sul, Brasil. Revista Brasileira de Ornitologia 14(2):45-46.

SilveIRA, V. P. \& GAN, M. A. 2006. Estudo de tendência das temperaturas mínimas na Região Sul do Brasil. In: CONGRESSO BRASILEIRO DE METEOROLOGIA, 14. Anais... Florianópolis, SBMET.
Soares, E. S.; Amaral, F. S. R.; Carvalho Filho, E. P. M.; Granzinollu, M. A.; Albuquerque, J. L. B.; Lisboa, J. S.; Azevedo, M. A. G.; Moraes, W.; Sanaiotti, T. \& Guimarães, I. G. 2008. Plano de ação nacional para a conservação de aves de rapina Brasília, Instituto Chico Mendes de Conservação da Biodiversidade (Série Espécies Ameaçadas, 5). 136p.

Straneck, R. 1990. Canto de las aves de los esteros y palmares. Buenos Aires, L.O.L.A. (audio cassete).

2007. Una nueva especie de Serpophaga (Aves: Tyrannidae). Revista FAVE - Ciencias Veterinarias 6(1-2):31-42.

Teixeira, E. M.; Bernardi, I. P. \& Jacomassa, F. A. F. 2009 Avifauna de Frederico Westphalen, Rio Grande do Sul, Brasil. Biotemas 22(4): 117-124.

Underdown, C. E. 1933. Notes on some birds from Santa Catharina, Brazil. Auk 50:323-324.

Vincent, L. A. Peterson, T. C.; Barros, V. R.; Marino, M. B.; Rusticucci, M.; Carrasco, G.; Ramirez, E.; Alves, L. M.; AmbrizZI, T.; Berlato, M. A.; Grimm, A. M.; Marengo, J. A.; Molion, L.; Moncunill, D. F.; Rebello, E.; Anunciação, Y. M. T.; Quintana, J.; Santos, J. L.; Baez, J.; Coronel, G.; Garcia, J.; Trebejo, I. Bidegain, M.; Haylock, M. R. \& Karoly, D. 2005. Observed trends in indices of daily temperature extremes in South America 1960-2000. Journal of Climate 18:5011-5023.

Zimmer, J. T. 1947. Studies of Peruvian birds. No. 51. The genera Chlorothraupis, Creurgops, Eucometis, Trichothraupis, Nemosia, Hemithraupis, and Thlypopsis, with additional notes on Piranga. American Museum Novitates (1345):1-23. 